\title{
Editorial: Hate Crimes
}

Blowing people up in the shopping centre of Warrington or of a provincial Irish town, or in a Jerusalem restaurant, flying planes full of people into heavily populated skyscrapers or centres of government, massacring defenceless villagers simply because they belong to another tribe. These are certainly hate crimes, that is, crimes fuelled by hate. For most of us the hate and the crime, when we watch such events unfold, are unimaginable. We cannot imagine what it is which can drive people in our time to do such things.

Terrorism must be outlawed once and for all, we think, surely rightly. Yet we are unsure how to do it. But there is a vague feeling that some of this terrorism arises from violent differences of belief, and from people being driven by their beliefs to kill those of other beliefs. But again, as liberals, we do not know how to handle this thought.

Perhaps things would be better if we could stop people saying and believing these hateful things. Or perhaps what is required is a kind of universal tolerance, a respect for the beliefs of others, so that they and their beliefs can be brought under the umbrella of tolerance, which will make them more tolerant in their turn.

This latter thought has been prominent in the utterances of Western leaders after September 11th; somewhat confusingly they say that what is at issue is not a question of belief, while at the same time falling over backwards to say that all beliefs must be tolerated and respected. In Britain a law was proposed by the Government to protect religious beliefs against ridicule and scorn. Incitement to 'religious hatred' was to become a criminal offence, although the attempt was in the end blocked by the House of Lords.

Philosophers may be no wiser or more experienced than anyone else when it comes to dealing with terrorism in general. But philosophers ought to be alert to any attempt, however well intentioned, to control thought and expression. Gibbon was unsparing in his mockery of Christianity, and so, in their own way, were Hume, Voltaire and Russell. They caused and continue to cause offence. Some religious people might find in their writings 'incitement to religious hatred'; it is indeed hard not to think that someone swayed by the rhetoric of Why I Am Not a Christian would not come to hate religion, and that surely was Russell's purpose. (And not just Christianity; unwisely, perhaps, from the Islamic point of view, the book used to be freely on sale in Pakistan, where the censors obviously failed to realize that Russell did not confine his tirade to 


\section{Editorial}

Christianity.) And what of the case of Salman Rushdie, on whom eminent philosophical opinion has been divided? We do not know exactly what the new law will say, but it is hard to think of any remotely effective law against religious hatred which, intentionally or unintentionally, would not convict The Satanic Verses; certainly it could not fail to do so if the feelings of the offended were taken into account in judging 'hatred', which is presumably a large part of the point of the new law.

No doubt in our liberal sensitivity, we generally want to avoid giving offence or succouring those who are deliberately offensive. There is something deeply offensive to the liberal mind about a certain type of rhetoric, Marx's, say, or Hitler's. But should we seek to censor the rhetoric, as opposed the deeds which may follow from it?

Part of our dilemma arises from the fact that some of those most vulnerable to the rhetoric of ridicule and scorn will be the very fanatics whose own outpourings fuel militant extremism. So, from a liberal point of view, ridicule and scorn-and so a certain type of incitement to religious hatred-might seem good.

At first blush this seems right. Despite what our leaders may say we should not passively tolerate those whose beliefs are intolerant. Rather we should contest those beliefs, vigorously, however offensive this might be to the believers. As we learn from Gibbon and the rest scorn and ridicule can be highly effective weapons against that sort of intolerance. In censoring ridicule and scorn we will be depriving ourselves of one of the strongest antidotes we have to the hate which kills, even if those scorned see themselves as thereby targets of hate. This antidote may be stronger and more effective in the war against hatred than censorship; for censorship may stop those of us who are in a broad sense liberals from saying what we really think about certain beliefs, while at the same time driving the most virulent expressions of those beliefs underground. Censorship, in other words, won't stop the beliefs, but it may well muzzle the most powerful weapon against them.

This is certainly not a final conclusion. But a debate there must be. And it is one in which philosophers, as guardians of the life of the mind, need to become involved. 